\title{
In Vitro and In Vivo Inhibitory Effects of Gaseous Chlorine Dioxide against Fusarium oxysporum f. sp. batatas Isolated from Stored Sweetpotato: Study II
}

\author{
Ye Ji Lee ${ }^{1 \dagger}$, Jin-Ju Jeong ${ }^{1, \dagger}$, Hyunjung Jin ${ }^{1}$, Wook Kim ${ }^{1}$, Young Chull Jeun ${ }^{3}$, Gyeong-Dan Yu ${ }^{4}$, and \\ Ki Deok Kim (1) ${ }^{1 *}$ \\ ${ }^{1}$ Department of Biosystems and Biotechnology, Korea University, Seoul 02841, Korea \\ ${ }^{2}$ Institute of Life Science and Natural Resources, Korea University, Seoul 02841, Korea \\ ${ }^{3}$ Faculty of Bioscience and Industry, College of Applied Life Sciences, Jeju National University, Jeju 63243, Korea \\ ${ }^{4}$ Bioenergy Crop Research Institute, National Institute of Crop Science, Rural Development Administration, Muan \\ 58521, Korea
}

(Received on April 3, 2019; Revised on July 1, 2019; Accepted on July 5, 2019)

Chlorine dioxide $\left(\mathrm{ClO}_{2}\right)$ has been widely used as an effective disinfectant to control fungal contamination during postharvest crop storage. In this study, Fusarium oxysporum f. sp. batatas SP-f6 from the black rot symptom of sweetpotato was isolated and identified using phylogenetic analysis of elongation factor 1- $\alpha$ gene; we further examined the in vitro and in vivo inhibitory activities of $\mathrm{ClO}_{2}$ gas against the fungus. In the in vitro medium tests, fungal population was significantly inhibited upon increasing the concentration and exposure time. In in vivo tests, spore suspensions were drop-inoculated onto sweetpotato slices, followed by treatment using various $\mathrm{ClO}_{2}$ concentrations and treatment times to assess fungus-induced disease development in the slices. Lesion diameters decreased at the tested $\mathrm{ClO}_{2}$ concentrations over time. When sweetpotato roots were dip-inoculated in spore suspensions prior to treatment with 20 and $40 \mathrm{ppm}$ of $\mathrm{ClO}_{2}$ for $0-60 \mathrm{~min}$, fungal populations significantly decreased at the tested concentrations for 30-60 min. Taken together, these re-

\footnotetext{
${ }^{\dagger}$ The first two authors contributed equally to this work. *Corresponding author.

Phone) +82-2-3290-3065, FAX) +82-2-925-1970

E-mail)kidkim@korea.ac.kr

ORCID

Ki Deok Kim

http://orcid.org/0000-0003-3985-0304

(c) This is an Open Access article distributed under the terms of the Creative Commons Attribution Non-Commercial License (http:// creativecommons.org/licenses/by-nc/4.0) which permits unrestricted noncommercial use, distribution, and reproduction in any medium, provided the original work is properly cited.
}

Articles can be freely viewed online at www.ppjonline.org. sults showed that $\mathrm{ClO}_{2}$ gas can effectively inhibit fungal growth and disease development caused by $F$. oxysporum f. sp. batatas on sweetpotato. Therefore, $\mathrm{ClO}_{2}$ gas may be used as a sanitizer to control this fungus during postharvest storage of sweetpotato.

Keywords : chlorine dioxide, elongation factor 1- $\alpha$ gene, Fusarium oxysporum f. sp. batatas, Fusarium wilt, sweetpotato

Handling Editor : Lee, Jungkwan

Chlorine has been widely applied to control postharvest diseases in various fruits and vegetables such as blueberries, cucumber, oranges, potatoes, strawberries, and tomatoes (Bhagat et al., 2011; Mahovic et al., 2007; Popa et al., 2007; Tweddell et al., 2003; Yuk et al., 2006). Chlorine has a strong oxidation activity on cellular constituents and combines directly with membrane proteins and enzymes (Tweddell et al., 2003). Chlorine, with these action traits, can destroy various microbes existing on fruits and vegetables. Owing to this ability, chlorine dioxide $\left(\mathrm{ClO}_{2}\right)$ could be used as an alternative sanitizer as its oxidation capacity is 2.5 times higher than that of chlorine (Beuchat et al., 2004). $\mathrm{ClO}_{2}$ works effectively and rapidly against microbes at low concentrations while its toxicity to human and animals is considered low (Vaid et al., 2010; Wang et al., 2016). Thus, $\mathrm{ClO}_{2}$ as a sanitizer has been approved for agricultural and medical uses by the United States Environmental Protection Agency (EPA) (2006). Recently, the application of gaseous $\mathrm{ClO}_{2}$ (e.g., $\mathrm{ClO}_{2}$ concentration, time, and temperature) against pathogenic microbes on posthar- 
vest stage and storage of various fruits and vegetables was well documented by Sun et al. (2019).

Sweetpotato (Ipomoea batatas Lam.) is one of the most important food crops worldwide (Sanusi et al., 2016). While the consumption of sweetpotato has increased, postharvest diseases (especially fungal contamination) during crop storage are significant limitations (estimated quantity and quality loss, 15-65\%) (Ray and Ravi, 2005). Sweetpotato is generally stored in storage houses, in which fungal contamination may spread throughout the storage facility, resulting in significant contamination of the stored crop (Wu and Rioux, 2010). Hence, it is important to apply effective control measures to prevent fungal infection during sweetpotato storage. Fungicides such as thiabendazole, dichloran, benomyl, and iprodione may be used to control root rots of sweetpotato in fields or to obtain diseasefree 'seed' roots for plant production (Clark et al., 2013). However, application of agricultural chemicals is generally avoided during sweetpotato storage because the crop roots are directly used as a food source. Thus, $\mathrm{ClO}_{2}$ gas, as described above, may be used as an alternative measure to control fungal contamination during crop storage.

Numerous Fusarium spp. have been reported to infect sweetpotato roots (Farr and Rossman, 2018); however, Fusarium wilt caused by Fusarium oxysporum f. sp. batatas is one of the major diseases of sweetpotato (Clark et al., 2013). Fusarium wilt is usually widespread and shows higher infection levels in commercial fields (Thompson et al., 2011). In Korea, this disease was first reported by Park (1967) and has caused significant economic losses in sweetpotato production areas such as Haenam. In general, Fusarium wilt symptoms include yellowing of older leaves followed by wilting, abscission of older leaves, and stunting of vine growth (Clark et al., 2013). The infection of sweetpotato plants by the pathogen can occur from soilborne inoculum such as chlamydospores. Thus, soil as a source of inoculum may also contribute to the infection of sweetpotato roots at harvest and root rot may follow during storage. In this sense, it is important to find measures to limit infection of the pathogen to sweetpotato roots (Clark et al., 2013).

Previously, we often observed black rot symptoms on stored sweetpotato roots and frequently isolated Fusarium spp. from the infected roots. We suspected the causal agent for this symptom to be the pathogen causing Fusarium wilt on sweetpotato plants in fields. Therefore, the objectives of this study were (1) to identify the causal agent of the black rot symptom of stored sweetpotato roots and (2) to evaluate in vitro and in vivo inhibitory activities of gaseous $\mathrm{ClO}_{2}$ against the causal agent isolated from sweetpotato at various $\mathrm{ClO}_{2}$ concentrations and treatment times.

\section{Materials and Methods}

Fungus and sweetpotato. Diseased sweetpotato roots (cv. 'Juwhangmi') supplied from the Bioenergy Crop Research Center, National Institute of Crop Science, Rural Development Administration (Muan, Korea) in August 2015 were used in this study (Fig. 1A and B). For fungal isolation, small pieces of tissues from the margins of the diseased root were cut and sterilized with $1 \% \mathrm{NaOCl}$ for $2 \mathrm{~min}$. The tissue pieces were then washed with sterile distilled water three times and blotted on a sterile filter paper (Whatman No. 1). The pieces were placed on acidified potato dextrose agar (PDA) supplemented with lactic acid $(600 \mu \mathrm{l} / \mathrm{l})$ at $25^{\circ} \mathrm{C}$. Two to three days after placement on the medium, hyphal tips of mycelia grown from tissue pieces (one per lesion) were transferred to acidified PDA. Obtained isolates were further stored on PDA slants at $4^{\circ} \mathrm{C}$ until use. A representative isolate SP-f6 from isolated cultures was selected and subjected to further identification. Isolate SPf6 was grown on Spezieller Nährstoffarmer agar (SNA) for macroconidium and microconidium formation (Leslie and Summerell, 2006). Healthy sweetpotato roots (cv. 'Juwhangmi') from the same center mentioned above were used in this study and these were stored in a moist chamber with $60 \%$ relative humidity at $15^{\circ} \mathrm{C}$ until use.
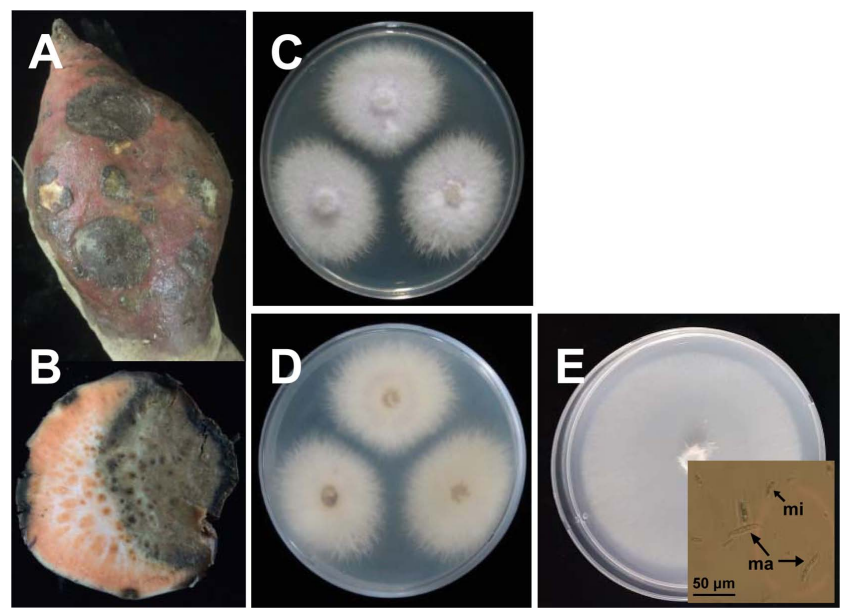

Fig. 1. (A) Outer and (B) inner black rot symptoms on sweetpotato (cv. 'Juwhangmi'). (C) Obverse and (D) reverse cultural morphologies of isolate SP-f6, isolated from a diseased sweetpotato, on potato dextrose agar at $25^{\circ} \mathrm{C}$ for 5 days in the dark. (E) Macroconidia and microconidia (inset) of isolate SP-f6 on Spezieller Nährstoffarmer agar. 
Molecular identification of isolate SP-f6. For molecular identification of isolate SP-f6 obtained from the diseased root tissue, the genomic DNA was extracted from fungal mycelia grown on PDA at $25^{\circ} \mathrm{C}$ for 7 days using an igenomic BYF DNA Extraction Kit (iNtRON Biotechnology, Seongnam, Korea) according to the manufacturer's instructions. The internal transcribed spacer (ITS) regions of isolate SP-f6 were amplified using the universal primers ITS1 (5'-TCCGTAGGTGAACCTGCGG-3') and ITS4 (5'-TCCTCCGCTTATTGATATGC-3') (Glass and Donaldson, 1995); the elongation factor $1-\alpha$ gene of the isolate was amplified with primers EF-1 (5'-ATGGGTAAGGAAGACAAGAC-3') and EF-2 (5'-GGAAGTACCAGTGATCATGTT-3') (Kim et al., 2005). Polymerase chain reaction and DNA sequence analysis were conducted as described by Kim et al. (2009) and Sang et al. (2013). The sequenced data were analyzed using the Basic Local Alignment Search Tool (BLAST) at the NCBI website (https://blast.ncbi.nlm.nih.gov/Blast.cgi). A phylogenetic tree was constructed using the neighbor-joining (Saitou and Nei, 1987) and maximum-likelihood (Fitch, 1971) algorithms using Molecular Evolutionary Genetics Analysis (MEGA) version 6.0. The topology of the tree was assessed by analyzing bootstrap with 1000 replications (Felsenstein, 1985). The experiments were performed twice for confirmation.

Pathogenicity test of isolate SP-f6. For pathogenicity tests of isolate SP-f6, healthy sweetpotato roots (cv. 'Juwhangmi') were washed with tap water and rinsed with distilled water. The roots were surface-sterilized with $70 \%$ ethanol for $5 \mathrm{~min}$. Then, these roots were rinsed with distilled water twice and dried for $10 \mathrm{~min}$ at $15^{\circ} \mathrm{C}$. The roots were hole-inoculated with isolate SP-f6 grown on PDA at $25^{\circ} \mathrm{C}$ for 7 days. Holes in roots were made using a sterile 4-mm cork-borer. Mycelial plugs (5 $\mathrm{mm}$ in diameter) from the edges of the growing cultures of isolate SP-f6 or PDA plugs (uninoculated control) were inoculated into holes made in the outer layers of the sweetpotato roots [six holes: three (sub-replicates) for SP-f6 and three for PDA plug per root (replicate)]. The inoculated roots were then wrapped up in polyethylene film (Cleanwrap Co., Seoul, Korea) and placed in moist plastic containers [23 (length) $\times 13$ (width) $\times 16$ (height) $\mathrm{cm}$ ] with three layers of wet paper towels $(100 \% \mathrm{RH})$ and incubated at $28^{\circ} \mathrm{C}$. After 10 days of incubation, lesion diameters $(\mathrm{mm})$ were measured. At the same time, fungus was re-isolated from the symptomatic tissues to fulfill Koch's postulates. The edges of lesions were cut, sterilized with $1 \% \mathrm{NaOCl}$ for $1.5-5 \mathrm{~min}$, washed three times with sterile distilled water, and blotted on a sterile filter paper (Whatman No. 1). These pieces were placed on acidified PDA at $25^{\circ} \mathrm{C}$ for 3 days. The mycelia grown from the pieces was transferred to PDA and the identity of the isolate reconfirmed by the elongation factor $1-\alpha$ gene sequence analysis, as described above.

In vitro effect of gaseous chlorine dioxide against isolate SP-f6 on medium. To examine the in vitro inhibitory effect of gaseous $\mathrm{ClO}_{2}$ against isolate SP-f6 on the medium, spore suspensions $(200 \mu \mathrm{l})$ of the isolate were spread on acidified PDA. Spores from cultures of isolate SP-f6 grown on PDA at $25^{\circ} \mathrm{C}$ for 7 days were harvested with $0.03 \%$ Tween 20 and adjusted to $5 \times 10^{3}$ spores $/ \mathrm{ml}$ using a hemocytometer. Next, these spore-inoculated plates were treated with various concentrations $(1,5,10$, and $20 \mathrm{ppm})$ of $\mathrm{ClO}_{2}$ gas for $0,1,10,30$, and $60 \mathrm{~min}$. The gas treatment for various treatment times was conducted using a $\mathrm{ClO}_{2}$ generator (PurgoFarm Co. Ltd., Hwaseong, Korea) with an electrochemical method (Gates, 1998), as described in our previous study (Lee et al., 2019). The gas-treated plates were further incubated at $25^{\circ} \mathrm{C}$. After 2 days of incubation, numbers of colony-forming units (CFUs) on the plates were counted.

In vivo effect of gaseous chlorine dioxide against isolate SP-f6 on root slices. To examine the in vivo inhibitory effect of gaseous $\mathrm{ClO}_{2}$ against isolate SP-f6 on root slices, healthy sweetpotato roots prepared as described in the pathogenicity test were cut into 1-cm-thick slices, and placed in Petri plates ( $90 \mathrm{~mm}$ in diameter). The centers of the slices were drop-inoculated with the spore suspension $\left(10 \mu \mathrm{l}\right.$ of $5 \times 10^{6}$ spores $\left./ \mathrm{ml}\right)$ prepared as described above. The inoculated slices were treated with various concentrations $(5,10$, and $20 \mathrm{ppm})$ of $\mathrm{ClO}_{2}$ gas for $0,10,30$, and 60 min, as described above. Next, the gas-treated slices were put in the plastic containers containing wet paper towels as described above and incubated at $28^{\circ} \mathrm{C}$ for 14 days. Then, lesion diameters on the gas-treated, inoculated slices were assessed as follows: longest lesion length $(\mathrm{mm})+$ shortest lesion length $(\mathrm{mm})$ were divided by two.

In vivo effect of gaseous chlorine dioxide against isolate SP-f6 on sweetpotato roots. To examine the in vivo inhibitory effect of gaseous $\mathrm{ClO}_{2}$ against isolate SP-f6 on sweetpotato, roots were dipped in spore suspension $\left(5 \times 10^{6}\right.$ spores $/ \mathrm{ml}$ ) prepared as described above, for $10 \mathrm{~min}$. The $0.03 \%$ Tween 20 was used as an uninoculated control. The inoculated roots were treated with different concentrations (20 and $40 \mathrm{ppm}$ ) of $\mathrm{ClO}_{2}$ gas for 0,30 , and $60 \mathrm{~min}$ as described above. Then, the surface layers (approximately 1.5 
$\mathrm{mm}$ in thickness) of the gas-treated roots were peeled using a vegetable peeler. Samples $(2 \mathrm{~g})$ were finely ground using an analytical mill (IKA A11 basic, IKA Works) in sterile distilled water $(20 \mathrm{ml})$. After serial dilutions of the ground sample solution, the samples were spread on acidified PDA and further incubated at $25^{\circ} \mathrm{C}$. After 2 days of incubation, colonies that appeared on the medium were counted; these were expressed as CFUs per $g$ dry weight.

Statistical analysis. Experiments were conducted using factorial designs to recognize the effects of $\mathrm{ClO}_{2}$ gas concentration and treatment time with various levels on lesion diameters and fungal populations. All experiments except molecular identification of the isolate were conducted twice with three replicates per treatment. Fungal population data from repeated experiments of the in vitro $\mathrm{ClO}_{2}$ inhibitory tests on the medium were pooled after confirmation of homogeneity of variances, using Levene's test (Levene, 1960). In addition, fungal population data in this study were analyzed after logarithmic transformation. Analysis of variance (ANOVA) was conducted using general linear model procedures; the means were separated using least significant difference (LSD) test at $P<0.05$. Statistical analysis of all data was conducted using Statistical Analysis Systems (SAS) software (SAS Institute, Cary, NC, USA).

\section{Results}

Fungal isolation and identification of isolate SP-f6. The potential causal fungus was consistently isolated from the margins of symptomatic lesions of diseased sweetpotato roots. Isolate SP-f6 randomly selected from isolates obtained from diseased sweetpotato roots (cv. Juwhangmi) showed white floccose mycelium and pink to purple reverse color (Fig. 1C and D); consequently, it was considered as the genus Fusarium. In addition, macroconidia and microconidia of isolate SP-f6 were observed on SNA medium (Fig. 1E).

For the phylogenetic analysis of isolate SP-f6, partial sequences (469 and 608 bases) of the ITS region and elongation factor $1-\alpha$ alpha genes, respectively, were analyzed. In the neighbor-joining analysis using the ITS region sequence, isolate SP-f6 was clustered with Fusarium oxysporum CBS 132475 (100\% similarity), Fusarium inflexum NRRL $20433^{\mathrm{T}}$ (99.28\% similarity), F. oxysporum f. sp. batatas CBS 258.50 (98.08\% similarity), and $F$. oxysporum f. sp. batatas CBS 172.30 (98.08\% similarity) (Supplementary Fig. 1). On the other hand, based on the neighbor-joining analysis of elongation factor $1-\alpha$ gene, isolate SP-f6 was clustered with $F$. oxysporum f. sp. bata-

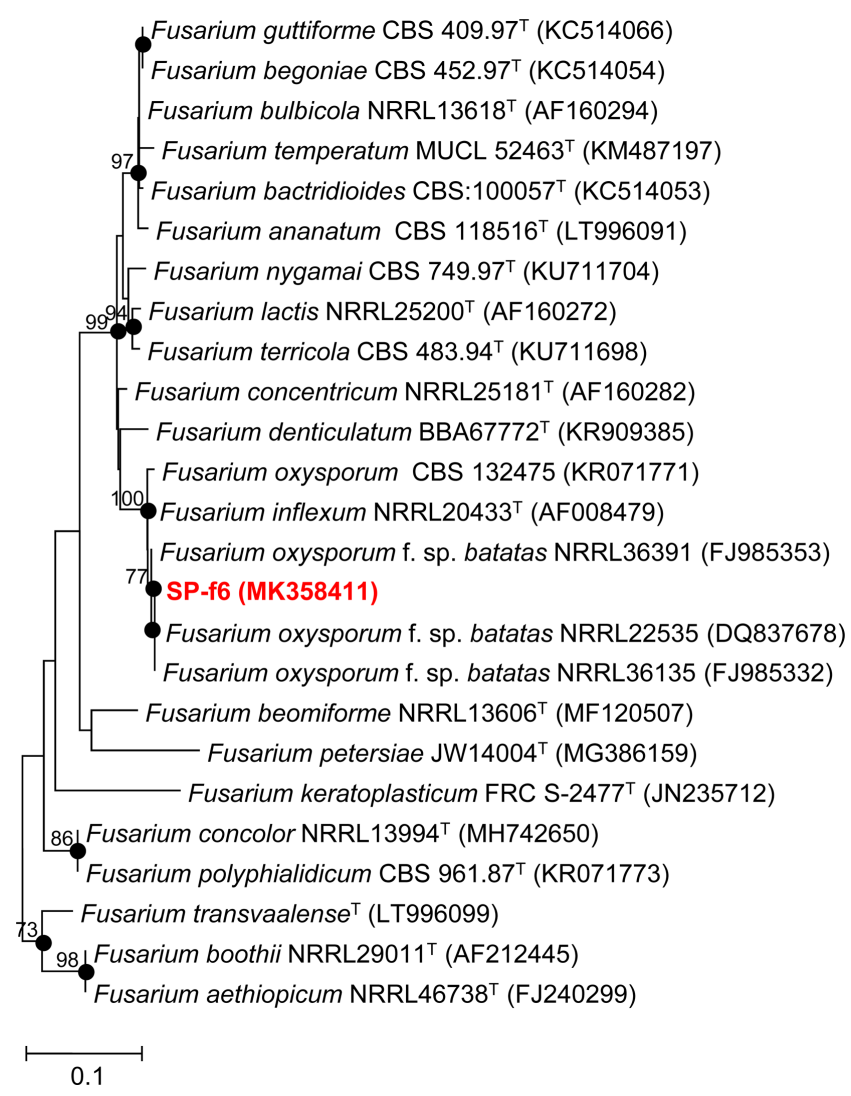

Fig. 2. Neighbor-joining tree that shows the relationships between isolate SP-f6 (MK358411) and related members of the genus Fusarium, based on phylogenetic analysis of elongation factor 1- $\alpha$ gene sequence. Filled circles on the branches indicate that the nodes were also recovered in the tree constructed by the maximum-likelihood algorithm. Microdochium nivale 200118 (KT736151) was used as an outgroup (not shown). Scale bar, $1 \mathrm{nt}$ substitution per $10 \mathrm{nt}$ of the sequence.

tas NRRL 22535 (100\% similarity), F. oxysporum f. sp. batatas NRRL 36135 (99.84\% similarity), F. oxysporum f. sp. batatas NRRL 36391 (98.84\% similarity), Fusarium inflexum NRRL $20433^{\mathrm{T}}$ (99.04 similarity), and Fusarium oxysporum CBS 132475 (99.04 similarity) (Fig. 2). Thus, isolate SP-f6 was clearly identified as $F$. oxysporum $\mathrm{f}$. sp. batatas based on the analysis of elongation factor 1- $\alpha$ gene sequence. The ITS (MK212928) and the elongation factor 1- $\alpha$ gene (MK358411) sequences of $F$. oxysporum $\mathrm{f}$. sp. batatas SP-f6 have been deposited in GenBank.

Pathogenicity of $F$. oxysporum f. sp. batatas SP-f6 on sweetpotato. In the pathogenicity test, $F$. oxysporum $\mathrm{f}$. sp. batatas SP-f6 caused dark grayish round lesions with white mycelia on sweetpotato (cv. Juwhangmi) roots 10 days after inoculation (Fig. 3A). Lesion diameters on outer layers of roots inoculated with isolate SP-f6 were $8.72 \pm$ 

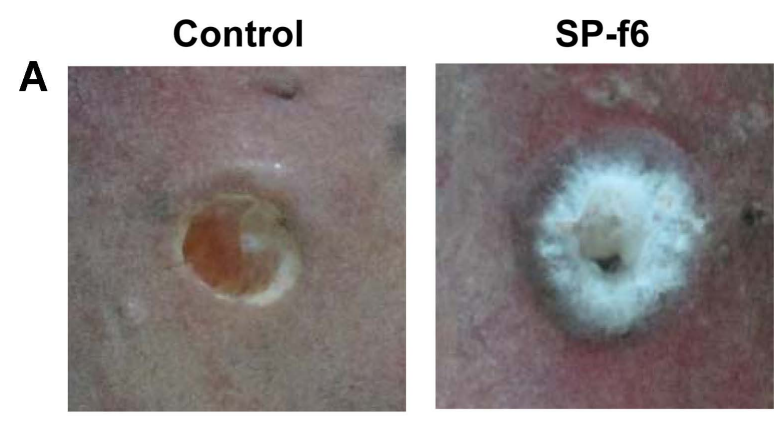

B
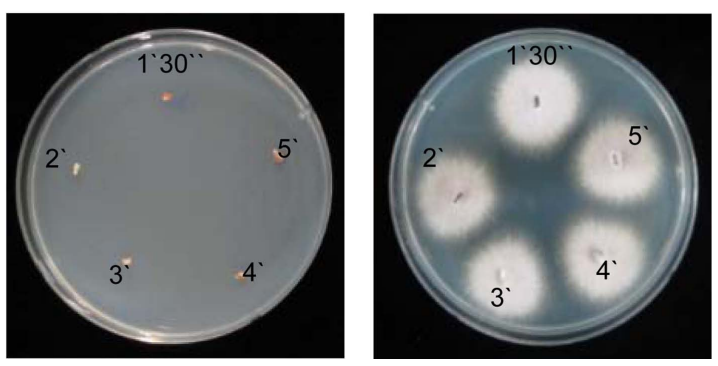

Fig. 3. (A) Symptoms of the sweetpotato roots at 10 days after hole-inoculation with Fusarium oxysporum f. sp. batatas SPf6. Mycelial potato-dextrose agar (PDA) plugs were inoculated by placing them in 5-mm holes that were made by a sterile corkborer on sweetpotato (cv. Juwhangmi). PDA plugs alone were used as uninoculated controls. (B) The inoculated fungal isolate was re-isolated on acidified PDA from (A) symptomatic tissues after surface-sterilization in $\mathrm{NaOCl}$ solution for 1.5-5 min; the recovered isolate was shown on acidified PDA 3 days after incubation at $25^{\circ} \mathrm{C}$.

$0.70 \mathrm{~mm}$ (mean \pm standard error) and $10.22 \pm 0.49 \mathrm{~mm}$ in repeated experiments. However, PDA plugs (uninoculated control) did not produce any symptoms on the root (Fig. 3A). To fulfill Koch's postulates, isolate SP-f6 was isolated again from the symptomatic tissues of the inoculated roots, in which the tissues were surface-sterilized with $\mathrm{NaOCl}$ for $5 \mathrm{~min}$ (Fig. 3B). This isolate was further confirmed as $F$. oxysporum f. sp. batatas SP-f6 by elongation factor $1-\alpha$ gene sequence analysis. However, fungal mycelia were not isolated from the PDA-inoculated controls (Fig. 3B).

In vitro effect of gaseous chlorine dioxide against $F$. oxysporum f. sp. batatas SP-f6 on medium. When the in vitro inhibitory effect of gaseous $\mathrm{ClO}_{2}$ against $F$. oxysporum $\mathrm{f}$. sp. batatas SP-f6 was tested on PDA, gaseous $\mathrm{ClO}_{2}$ at various concentrations and exposure times affected the growth of isolate SP-f6 (Fig. 4). Fungal population was significantly inhibited at $1 \mathrm{ppm}$ of $\mathrm{ClO}_{2}$ for $30 \mathrm{~min}$ and was almost completely suppressed at $1 \mathrm{ppm}$ for $60 \mathrm{~min}$ and $5 \mathrm{ppm}$ for $5 \mathrm{~min}$. Furthermore, $\mathrm{ClO}_{2}$ gas treatment at $5 \mathrm{ppm}$ for 30-60 min and 10 and $20 \mathrm{ppm}$ for $10-60$ min completely inhibited the fungal population on medium (Fig. 4).
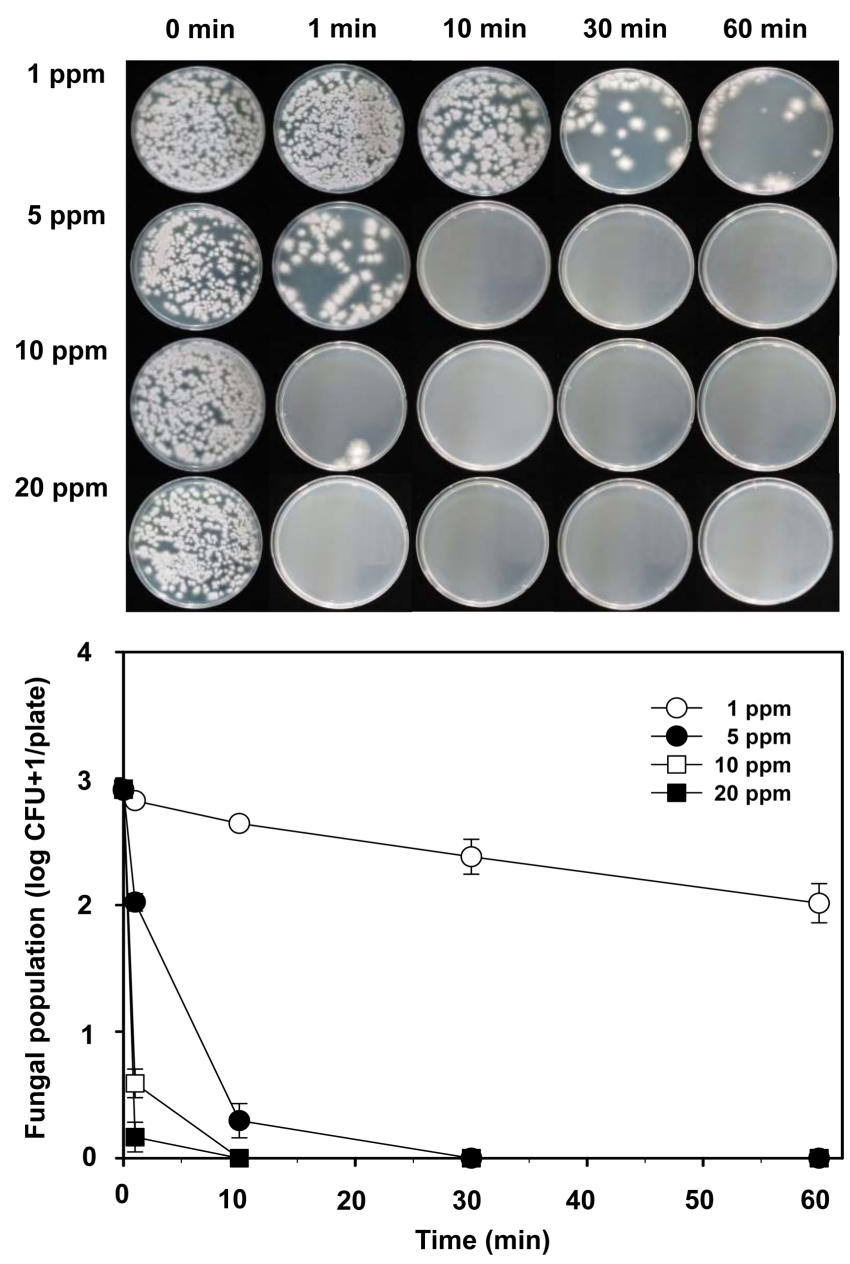

Fig. 4. Photographs (top) and populations (below) of Fusarium oxysporum f. sp. batatas SP-f6 on acidified potato dextrose agar (PDA) treated with various $\mathrm{ClO}_{2}$ concentrations $(1,5,10$, and 20 ppm) for $0,1,10,30$, and $60 \mathrm{~min}$. Colony-forming units (CFUs) were determined 2 days after incubation. Spore suspension (200 $\mu \mathrm{l}$ of $5 \times 10^{3}$ spores $/ \mathrm{ml}$ ) of isolate SP-f6 was spread on acidified PDA before $\mathrm{ClO}_{2}$ gas treatments. Error bars = standard deviations of the means $(n=6)$.

In vivo effect of gaseous chlorine dioxide against $F$. oxysporum f. sp. batatas SP-f6 on root slices. Lesion diameters caused by $F$. oxysporum f. sp. batatas SP-f6 in the inoculated sweetpotato slices decreased with an increase in $\mathrm{ClO}_{2}$ concentrations and exposure times in experiment 2, but not in experiment 1 (Fig. 5A, Supplementary Table 1). $\mathrm{ClO}_{2}$ concentration $(P=0.0013)$ and exposure duration $(P<0.0001)$ significantly affected lesion diameters on the inoculated slices in experiment 2, but not in experiment 1 (Supplementary Table 1). Significant concentration and time interactions $(P=0.9415$ for experiment 1 and $P=$ 0.1258 for experiment 2) for lesion diameters were not observed in either experiment (Supplementary Table 1). The 

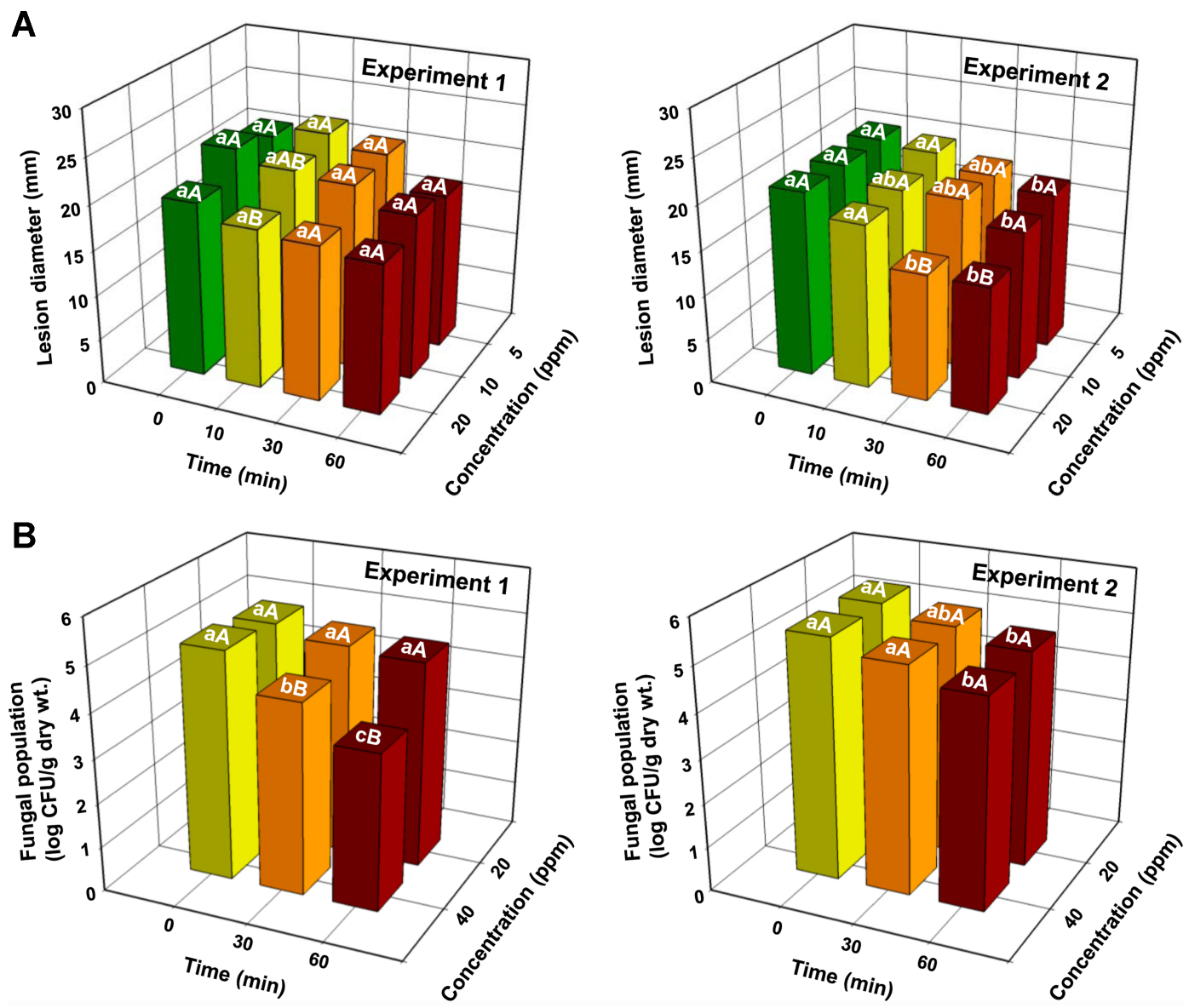

Fig. 5. (A) Lesion diameters and (B) fungal populations on sweetpotato slices and surface layers of roots inoculated with Fusarium oxysporum $\mathrm{f}$. sp. batatas SP-f6, followed by treatments with gaseous chlorine dioxide $\left(\mathrm{ClO}_{2}\right)$, respectively. Sweetpotato slices were dropinoculated with spore suspension $\left(10 \mu \mathrm{l}\right.$ of $\left.5 \times 10^{6} \mathrm{spores} / \mathrm{ml}\right)$ of isolate SP-f6, followed by treatment with various concentrations $(5$, 10 , and $20 \mathrm{ppm})$ of $\mathrm{ClO}_{2}$ gas for $0,10,30$, and $60 \mathrm{~min}$. Roots were dipped in spore suspension $\left(5 \times 10^{6} \mathrm{spores} / \mathrm{ml}\right)$ for $10 \mathrm{~min}$ and then treated with different $\mathrm{ClO}_{2}$ concentrations $(20$ and $40 \mathrm{ppm})$ for 0,30 , and $60 \mathrm{~min}$. Different lowercase and uppercase letters on bars $(n=$ 3 ) are significantly different between time at a given concentration and between concentrations at a given time according to the least significant difference test at $P<0.05$, respectively.

degree of darkness of lesions declined over time, regardless of gas concentration. In addition, root slice tissues were lignified after gas treatment, especially at $20 \mathrm{ppm}$ for 30-60 min (Supplementary Fig. 2). However, disease symptoms were not observed in uninoculated sweetpotato slices (Supplementary Fig. 2).

In vivo effect of gaseous chlorine dioxide against $F$. oxysporum f. sp. batatas SP-f6 on sweetpotato roots. When the in vivo inhibitory effect of gaseous $\mathrm{ClO}_{2}$ against $F$. oxysporum f. sp. batatas SP-f6 was tested on sweetpotato roots, growth of isolate SP-f6 was significantly inhibited by $\mathrm{ClO}_{2}$ gas treatment at $40 \mathrm{ppm}$ for 30-60 min in experiment 1 and at 20 and $40 \mathrm{ppm}$ for $60 \mathrm{~min}$ in experiment 2 (Fig. $5 \mathrm{~B}) . \mathrm{ClO}_{2}$ gas treatment at $40 \mathrm{ppm}$ inhibited more population of isolate SP-f6 than the gas treatment at $20 \mathrm{ppm}$ for
30 and $60 \mathrm{~min}$ in experiment 1 (Fig. 5B). The concentration of $\mathrm{ClO}_{2}$ showed significant $(P=0.0001)$ inhibition on fungal population in an experiment; treated time exhibited significant $(P=0.0001$ for experiment 1 and $P=0.0003$ for experiment 2) reduction of fungal populations in both experiments (Supplementary Table 1). Significant $(P=$ 0.0002 ) concentration and time interactions for fungal populations were observed in experiment 1 (Supplementary Table 1).

\section{Discussion}

In this study, we isolated fungal isolate SP-f6 from the black rot lesion on a diseased sweetpotato root and identified it as $F$. oxysporum f. sp. batatas using phylogenetic analysis of the elongation factor 1- $\alpha$ gene. Furthermore, 
we tested whether $\mathrm{ClO}_{2}$ gas had inhibitory activity against the development and growth of $F$. oxysporum $\mathrm{f}$. sp. batatas on sweetpotato. We found that $\mathrm{ClO}_{2}$ gas suppressed fungal population and infection on sweetpotato roots. In addition, we observed that treatment time had a greater inhibitory effect than the $\mathrm{ClO}_{2}$ gas concentration on disease development and fungal population on sweetpotato.

$\mathrm{ClO}_{2}$ gas as a disinfectant has been widely used to control food-borne or postharvest microbial contamination on storage crops (Bhagat et al., 2011; Du et al., 2002; Yuk et al., 2006); thus, we examined the efficiency of $\mathrm{ClO}_{2}$ gas in controlling $F$. oxysporum f. sp. batatas-mediated infection in stored sweetpotato. In in vitro medium tests, the growth of $F$. oxysporum f. sp. batatas SP-f6 was significantly inhibited when treated with $1 \mathrm{ppm} \mathrm{ClO}_{2}$ gas for 30-60 min. Furthermore, growth of the fungus was completely inhibited following treatment with increased $\mathrm{ClO}_{2}$ concentration of 5 ppm for 30-60 min and 10 and $20 \mathrm{ppm}$ for 10-60 min. In our previous study, Diaporthe batatas was shown to have similar growth inhibition pattern against various $\mathrm{ClO}_{2}$ concentrations and exposure times (Lee et al., 2019). There are several other studies that demonstrate in vitro inhibitory activity of $\mathrm{ClO}_{2}$ on various fungal contaminations on crops. Chen and Zhu (2011) reported that treatment of chestnut with $7 \mathrm{mg} / 1$ of $\mathrm{ClO}_{2}$ for $15 \mathrm{~min}$ led to a 4.6-log reduction of Fusarium tricinctum spores, whereas a 5.0-log reduction in Dothiorella gregaria spores was detected under the same treatment conditions. Wu et al. (2011) observed that spore germination rate of litchi anthracnose pathogens (Colletotrichum spp.) was significantly inhibited following treatment with $5 \mathrm{mg} / \mathrm{l}$ of $\mathrm{ClO}_{2}$ solution. In addition, Sun et al. (2017) found that aqueous $\mathrm{ClO}_{2}$ significantly inactivated spores of Fusarium graminearum, the causal agent of Fusarium head blight of wheat.

In in vivo inoculation tests on sweetpotato slices, lesion diameters were significantly restricted when the slices were treated with $\mathrm{ClO}_{2}$ gas for $30 \mathrm{~min}$ at $20 \mathrm{ppm}$ treatment. Treatment for $60 \mathrm{~min}$ led to decrease in lesion diameters at all concentrations of the gas tested. However, lesion darkness, which indicates fungal growth and development, on slices turned lighter over time, and the tissues were lignified after gas treatment especially following the $60 \mathrm{~min}-$ treatment, regardless of the $\mathrm{ClO}_{2}$ concentration used. Tissue lignification resulting from gas treatment may not be a cause for concern as $\mathrm{ClO}_{2}$ gas is usually applied on sweetpotato roots. In in vivo root dip-inoculation tests followed by $\mathrm{ClO}_{2}$ gas treatment, fungal populations were reduced as observed in the slice tests. The inhibitory effect of $\mathrm{ClO}_{2}$ gas in this study followed a pattern similar to that observed in our previous study (Lee et al., 2019). These previous and present results imply that the $\mathrm{ClO}_{2}$ gas may have wide antifungal or antimicrobial activities beneficial for stored crops. In this regard, Bhagat et al. (2011) showed that $\mathrm{ClO}_{2}$ gas treatment inhibited Salmonella growth on oranges. They spot-inoculated a mixed culture of four Salmonella strains on the surface of orange and then treated the fruits with $0.1,0.3$, and $0.5 \mathrm{mg} / \mathrm{C} \mathrm{ClO}_{2}$ gas for $2-14 \mathrm{~min}$ at $22^{\circ} \mathrm{C}$ and $90-95 \%$ relative humidity. Consequently, a 5-log reduction of Salmonella per sample was observed with 0.1 and $0.3 \mathrm{mg} / 1 \mathrm{ClO}_{2}$ gas treatments at $14 \mathrm{~min}$, and $0.5 \mathrm{mg} / 1$ $\mathrm{ClO}_{2}$ gas at $10 \mathrm{~min}$. Moreover, Sy et al. (2005) also found similar reductions in populations of foodborne pathogens such as Escherichia coli, Salmonella, Listeria monocytogenes, yeasts, and molds when the inoculated fresh and fresh-cut produces were exposed to $4.1 \mathrm{mg} / 1 \mathrm{ClO}_{2}$ gas.

Taken together, the results in this study showed that $\mathrm{ClO}_{2}$ gas can effectively inhibit fungal population and infection by $F$. oxysporum f. sp. batatas on sweetpotato. $\mathrm{The}^{\mathrm{ClO}_{2}}$ gas treatment with $40 \mathrm{ppm}$ for 30-60 min may produce a desirable outcome by controlling the fungal growth and symptom development on the crop. Therefore, $\mathrm{ClO}_{2}$ gas may be used as a sanitizer to control $F$. oxysporum $\mathrm{f}$. sp. batatas during postharvest storage of sweetpotato.

\section{Acknowledgments}

This work was carried out with the supports of "Cooperative Research Program for Agriculture Science \& Technology Development (Project No. PJ011332)" of Rural Development Administration, Republic of Korea and Korea University, Seoul, Republic of Korea. J.-J. Jeong was supported by the Global Ph.D. program through the National Research Foundation of Korea funded by the Ministry of Education (2015-034526) in Korea.

\section{Electronic Supplementary Material}

Supplementary materials are available at The Plant Pathology Journal website (http://www.ppjonline.org/).

\section{References}

Beuchat, L. R., Pettigrew, C. A., Tremblay, M. E., Roselle, B. J. and Scouten, A. J. 2004. Lethality of chlorine, chlorine dioxide, and a commercial fruit and vegetable sanitizer to vegetative cells and spores of Bacillus cereus and spores of Bacillus thuringiensis. J. Food Prot. 67:1702-1708.

Bhagat, A., Mahmoud, B. S. and Linton, R. H. 2011. Effect of chlorine dioxide gas on Salmonella enterica inoculated on navel orange surfaces and its impact on the quality attributes of treated oranges. Foodborne Pathog. Dis. 8:77-85. 
Chen, Z. and Zhu, C. 2011. Modelling inactivation by aqueous chlorine dioxide of Dothiorella gregaria Sacc. and Fusarium tricinctum (Corda) Sacc. spores inoculated on fresh chestnut kernel. Lett. Appl. Microbiol. 52:676-684.

Clark, C. A., Ferrin, D. M., Smith, T. P. and Holmes, G. J. 2013. Compendium of sweetpotato diseases, pests, and disorders. 2nd ed. APS Press, St. Paul, MN, USA. 160 pp.

Du, J., Han, Y. and Linton, R. H. 2002. Inactivation by chlorine dioxide gas $\left(\mathrm{ClO}_{2}\right)$ of Listeria monocytogenes spotted onto different apple surfaces. Food Microbiol. 19:481-490.

Farr, D. F. and Rossman, A. Y. 2018. Fungal databases. U.S. National Fungus Collections, ARS, USDA. URL https://nt.arsgrin.gov/fungaldatabases/ [16 October 2018].

Felsenstein, J. 1985. Confidence limits on phylogenies: an approach using the bootstrap. Evolution 39:783-791.

Fitch, W. M. 1971. Towards defining the course of course of evolution: Minimum change for a specific tree topology. Syst. Zool. 20:406-416.

Gates, D. J. 1998. The chlorine dioxide handbook (Water disinfection series). American Water Works Association, Denver, CO, USA. 186 pp.

Glass, N. L. and Donaldson, G. C. 1995. Development of primer sets designed for use with the PCR to amplify conserved genes from filamentous ascomycetes. Appl. Environ. Microbiol. 61:1323-1330.

Kim, Y., Hutmacher, R. B. and Davis, R. M. 2005. Characterization of California isolates of Fusarium oxysporum $\mathrm{f}$. sp. vasinfectum. Plant Dis. 89:366-372.

Kim, H. S., Sang, M. K., Myung, I. S., Chun, S. C. and Kim, K. D. 2009. Characterization of Bacillus luciferensis strain KJ2C12 from pepper root, a biocontrol agent of Phytophthora blight of pepper. Plant Pathol. J. 25:62-69.

Lee, Y. J., Jeong, J.-J., Jin, H., Kim, W., Yu, G.-D. and Kim, K. D. 2019. In vitro and in vivo inhibitory effects of gaseous chlorine dioxide against Diaporthe batatas isolated from stored sweetpotato. Plant Pathol. J. 35:77-83.

Levene, H. 1960. Robust tests for equality of variances. In: Contributions to probability and statistics: essays in honor of Harold Hotelling, eds. by I. Olkin, S. G. Ghurye, W. Hoeffding, W. G. Madow and H. B. Mann, pp. 278-292. Stanford University Press, Stanford, CA, USA.

Leslie, J. F. and Summerell, B. A. 2006. The Fusarium laboratory manual. Blackwell Publishing, Ames, IA, USA. 388 pp.

Mahovic, M. J., Tenney, J. D. and Bartz, J. A. 2007. Applications of chlorine dioxide gas for control of bacterial soft rot in tomatoes. Plant Dis. 91:1316-1320.

Park, J. S. 1967. Fungous diseases of plant in Korea. Chungnam National University, Daejeon, Korea. 86 pp.

Popa, I., Hanson, E. J., Todd, E. C., Schilder, A. C. and Ryser, E. T. 2007. Efficacy of chlorine dioxide gas sachets for enhancing the microbiological quality and safety of blueberries. J. Food Prot. 70:2084-2088.

Ray, R. C. and Ravi, V. 2005. Post-harvest spoilage of sweet potato in tropics and control measures. Crit. Rev. Food Sci. Nutr. 45:634-644.
Sang, M. K., Kim, H. S., Myung, I. S., Ryu, C. M., Kim, B. S. and Kim, K. D. 2013. Chryseobacterium kwangjuense sp. nov., isolated from pepper (Capsicum annuum L.) root. Int. J. Syst. Evol. Microbiol. 63:2835-2840.

Saitou, N. and Nei, M. 1987. The neighbor-joining method: A new method for reconstructing phylogenetic trees. Mol. Biol. Evol. 4:406-425.

Sanusi, M. M., Lawal, O. I., Sanusi, R. A. and Adesogan, A. O. 2016. Profitability of sweet potato production in derived savannah zone of Ogun State, Nigeria. J. Agric. Soc. Res. 16:16-27.

Sun, C., Zhu, P., Ji, J., Sun, J., Tang, L., Pi, F. and Sun, X. 2017. Role of aqueous chlorine dioxide in controlling the growth of Fusarium graminearum and its application on contaminated wheat. LWT-Food Sci. Technol. 84:555-561.

Sun, X., Baldwin, E. and Bai, J. 2019. Applications of gaseous chlorine dioxide on postharvest handling and storage of fruits and vegetables: a review. Food Control 95:18-26.

Sy, K. V., Murray, M. B., Harrison, M. D. and Beuchat, L. R. 2005. Evaluation of gaseous chlorine dioxide as a sanitizer for killing Salmonella, Escherichia coli O157:H7, Listeria monocytogenes, yeasts, and molds on fresh and fresh-cut produce. J. Food Prot. 68:1176-1187.

Thompson, A. H., Narayanin, C. D., Smith, M. F. and Slabbert, M. M. 2011. A disease survey of Fusarium wilt and Alternaria blight on sweet potato in South Africa. Crop Prot. 30:14091413.

Tweddell, R. J., Boulanger, R. and Arul, J. 2003. Effect of chlorine atmospheres on sprouting and development of dry rot, soft rot and silver scurf on potato tubers. Postharvest Biol. Technol. 28:445-454.

United States Environmental Protection Agency. 2006. Reregistration eligibility decision (RED) for chlorine dioxide and sodium chlorite (Case 4023). URL https:/www3.epa.gov/ pesticides/chem_search/reg_actions/reregistration/red_PC020503_3-Aug-06.pdf [16 August 2018].

Vaid, R., Linton, R. H. and Morgan, M. T. 2010. Comparison of inactivation of Listeria monocytogenes within a biofilm matrix using chlorine dioxide gas, aqueous chlorine dioxide and sodium hypochlorite treatments. Food Microbiol. 27:979984.

Wang, T., Qi, J., Wu, J., Hao, L., Yi, Y., Lin, S. and Zhang, Z. 2016. Response surface modeling for the inactivation of $B a$ cillus subtilis subsp. niger spores by chlorine dioxide gas in an enclosed space. J. Air Waste Manage. Assoc. 66:508-517.

Wu, V. C. and Rioux, A. 2010. A simple instrument-free gaseous chlorine dioxide method for microbial decontamination of potato during storage. Food Microbiol. 27:179-184.

Wu, B., Li, X., Hu, H., Liu, A. and Chen, W. 2011. Effect of chlorine dioxide on the control of postharvest diseases and quality of litchi fruit. Afr. J. Biotechnol. 10:6030-6039.

Yuk, H. G., Bartz, J. A. and Schneider, K. R. 2006. The effectiveness of sanitizer treatments in inactivation of Salmonella spp. from bell pepper, cucumber, and strawberry. J. Food Sci. 71:95-99. 